Mycologia, 106(4), 2014, pp. 746-756. DOI: 10.3852/13-288

(C) 2014 by The Mycological Society of America, Lawrence, KS 66044-8897

\title{
Common, unsightly and until now undescribed: Fumiglobus pieridicola sp. nov., a sooty mold infesting Pieris japonica from western North America
}

Tanay Bose

Department of Botany, University of British Columbia, 6270 University Blvd., Vancouver, British Columbia V6T 1Z4, Canada, and Forestry and Agricultural Biotechnology Institute (FABI), University of Pretoria, 74 Lunnon Road, Hillcrest, Pretoria 0002, South Africa

Don R. Reynolds

University and Jepson Herbaria, 1001 Valley Life Sciences Building, University of California, Berkeley, California 94720-2465

Mary L. Berbee ${ }^{1}$

Department of Botany, University of British Columbia, 6270 University Blvd., Vancouver, British Columbia V6T 1Z4, Canada

Abstract: Sooty molds (Capnodiaceae) are saprotrophs on the surfaces of leaves, and they take their nutrients from honeydew exuded by sap-sucking insects. We describe and illustrate the sooty mold Fumiglobus pieridicola sp. nov., which, to the dismay of gardeners, forms a thick black mycelial coating on the leaves and twigs of ornamental Japanese andromeda (Pieris japonica) in western North America. As a mitosporic species with a pycnidium that lacks an elongated neck and has at most a rudimentary stalk, the species belongs in the genus Fumiglobus. Although locally common, we found no specimens identified under Fumiglobus or its synonyms in regional herbaria and no record of any similar fungus in host indices. Our species differs from others in Fumiglobus in having smaller pycnidia and conidia and in having intercalary as well as apical pycnidia. We determined partial $18 \mathrm{~S}$ and $28 \mathrm{~S}$ ribosomal gene sequences for $F$. pieridicola, the first for any Fumiglobus species. Sequence analysis provides strong bootstrap support for including Fumiglobus within Capnodiaceae. We also determined $18 \mathrm{~S}$ and $28 \mathrm{~S}$ sequences for the type species of the mitosporic genus Conidiocarpus, also in Capnodiaceae. We confirm that Conidiocarpus is the anamorph of Phragmocapnias. Following the rules of nomenclatural priority, we propose the new combinations Conidiocarpus asiaticus, Conidiocarpus betle, Conidiocarpus callitris, Conidiocarpus fuliginodes, Conidiocarpus heliconiae, Conidiocarpus imperspicuus and Conidiocarpus siamensis.

Submitted 6 Sep 2013; accepted for publication 5 Mar 2014.

${ }^{1}$ Corresponding author. E-mail: mary.berbee@gmail.com
We hope that describing the mystery fungus from our region and providing sequences for its molecular identification will lead to new studies on its biology and distribution.

Key words: Capnodiaceae, Conidiocarpus, Ericaceae, Fumiglobus, Pieris, scale insects

\section{INTRODUCTION}

This study focuses on an unidentified sooty mold that colonizes Pieris japonica (Ericaceae, common name Japanese andromeda), an introduced ornamental shrub. Defined strictly, sooty molds are almost always associated with sap-sucking insects and they use the honeydew produced by the insects as a nutritive substrate (Blakeman and Fokkema 1982, 2011; Kelly 1990; Andrew 1992; James et al. 2007; Dhami et al. 2013). Their name comes from their darkly pigmented mycelium, which forms a felt-like layer on plant leaves or stems (Stevens 1931, Hughes 1976, Reynolds 1976). As is typical for sooty molds, our unknown fungus was associated with scale insects, and it formed a black layer coating leaves of the Japanese andromeda. The fungus is locally common along Canada's west coast.

Sooty molds on ericaceous plants are mentioned in home gardening advice columns and university extension handbooks from North America (Buczacki et al. 1981, Hollingsworth 2013). Mycelia on the leaves do not directly parasitize the plant but instead block sunlight, which may lead to premature chlorosis and leaf fall (Buczacki et al. 1981). Gardeners are advised to treat the unsightly fungus with an insecticide to kill the insects that feed on the plant. Schread (1970) reported that a sooty mold damaged Japanese andromeda but without providing locality data or a voucher.

In contrast to the occasional mention of sooty molds in informal literature, we found no formal record in peer-reviewed literature or in herbaria of a species related to ours from the Pacific Northwest or from western Canada. The sooty mold on andromeda produces pycnidia with fimbriae surrounding their ostioles, suggesting that the species is a member of Capnodiaceae. (1915). The species has other capnodiaceous characters as well, including superficial interwoven mycelium and hyphae that are composed of darkly pigmented cells with constricted septa and with mucilaginous outer walls (Batista and Ciferri 1963b, 
Hughes 1976, Chomnunti et al. 2011). The pycnidia lack a neck and have at most a rudimentary stalk (Reynolds and Gilbert 2006), suggesting that the fungus is a species of Fumiglobus (= Asbolisia). Fumiglobus, a genus comprising seven tropical species from varied host families (Batista and Ciferri 1963b, Sharma and Agarwal 1977), had not been reported from temperate North America north of California (Farr DF, Rossman AY. Fungal databases, Systematic Mycology and Microbiology Laboratory, ARS, USDA. Retrieved 26 Jul 2013, from http://nt.ars-grin.gov/fungaldatabases/).

In terms of resources for identification, Fraser (1935) produced the first monograph for capnodiaceous sooty molds, encompassing both sexual and asexual taxa as the Eucapnodieae. Batista and Ciferri (1963a) segregated the sooty molds into two groups, placing the sexual forms in Capnodiaceae while moving the mitosporic molds to the newly erected family Asbolisiaceae (Batista and Ciferri 1963b). Currently the family Capnodiaceae includes 12 genera and 117 species, mostly with uncertain phylogenetic placements (Khodaparast 2006, Kirk et al. 2008, Lumbsch and Huhndorf 2010, Chomnunti et al. 2011).

The epiphyllous colonies of sooty molds often are composed of several species of capnodiaceous fungi (Hughes 1976, Chomnunti et al. 2011, Dhami et al. 2013), making them a challenge for molecular analysis. Reynolds (1998) used small subunit (SSU) rDNA data in the first molecular phylogenetic analysis of sooty molds. Reynolds' study included two sexual and three asexual species from Capnodiaceae. Schoch et al. (2006, 2009a) included a limited number of taxa from Capnodiaceae in a phylogenetic survey of Dothideomycetes, and Chomnunti et al. (2011) produced the first multigene phylogeny of the family.

Herein we identify the unknown sooty mold on Japanese andromeda as a new species of Fumiglobus, "Fumiglobus pieridicola", with comparisons with available herbarium specimens and published descriptions. Using a phylogeny from the nuclear ribosomal large and small subunit genes, we analyze the relationships of the unknown species to other species in the Capnodiaceae and Capnodiales.

\section{MATERIALS AND METHODS}

Fungal and insect specimens.-We collected sooty mold growing on Japanese andromeda in Vancouver, British Columbia, Canada, and Corvallis, Oregon, USA. We also looked for herbarium specimens of sooty molds in Capnodiaceae and borrowed Capnodium walteri specimens from DAVFP, the herbarium of Pacific Forestry Centre, Canadian Forest Service, Victoria, British Columbia. Conidiocarpus caucasicus (Gilan University Mycological Herbarium GUMH 937 and University of British Columbia Herbarium UBC F23755) was collected from Nashtārūd,
Māzandarān province, Iran, by F. Byrami in Jun 2011. We borrowed holotypes of Fumiglobus species from the University Herbarium (UC), University of California at Berkeley. These herbarium specimens of other Fumiglobus species were useful for morphological study but were too small and fragile for DNA extraction.

We collected the female insects that were associated with the sooty mold on Japanese andromeda from Vancouver and preserved them in ethanol $(70 \%)$ or dried them at $40 \mathrm{C}$. The preserved insects were forwarded to Gillian W. Watson, senior insect biosystematist, California Department of Food \& Agriculture, Sacramento, for identification.

Light microscopy.-Fresh fungal tissues were mounted in water. Dried fungal materials (including holotypes) were placed in 5\% aqueous $\mathrm{KOH}$ solution for 2-5 min, then mounted in water. Mean values of 50-100 measurements are indicated with the range in parentheses. Freehand drawings were made at a fixed scale, and photographs were taken with a Leica DFC420 digital color camera and a Leitz ${ }^{\circledR}$ DMRB DIC research microscope. The photograph of insects associated with Japanese andromeda was taken with DFC490 digital color camera attached to a Leica M205C stereomicroscope.

DNA extraction, amplification and sequencing.-We extracted total genomic DNA from the fresh fungal tissue of the unknown sooty mold and from dried tissue of Conidiocarpus caucasicus with DNeasy ${ }^{\circledR}$ Plant Mini Kit (QIAGEN Inc., Canada) following the manufacturer's protocol. The nuclear LSU and SSU rDNA regions for all three fungal specimens were amplified with fungal specific primer pairs LROR/LR8 (Vilgalys unpubl ${ }^{2}$, unpubl ${ }^{3}$ ), LR3R/LR9 (un$\mathrm{publ}^{3}$ ), LR7R/LR12 (Vilgalys and Hester 1990), LR8R/ LR11 (unpubl ${ }^{3}$ ) and NS1/NS4 (White et al. 1990), NS3/NS8 (White et al. 1990) and NS19/NS6 (White et al. 1990, Gargas and Taylor 1992) respectively.

When the SSU gene sequences for the unknown sooty mold showed evidence of contamination (apparently due to a mixed population of fungi on the leaf surface) we cloned the PCR products with $\mathrm{TOPO}^{\circledR}$ TA Cloning ${ }^{\circledR}$ Kits (Life Technologies, Canada). The PCR reactions were carried out with initial denaturation at $94 \mathrm{C}$ for $5 \mathrm{~min}$, followed by 40 cycles of $94 \mathrm{C}$ for $10 \mathrm{~s}, 55 \mathrm{C}$ for $20 \mathrm{~s}, 72 \mathrm{C}$ for $3 \mathrm{~min}$ and final elongation at $72 \mathrm{C}$ for $7 \mathrm{~min}$. The PCR products were sequenced with an ABI PRISM BigDye ${ }^{\circledR}$ Terminator Cycle Sequencing Kit 3.1 (Life Technologies-Applied Biosystems, Canada). The Nucleic Acid-Protein Service Unit in the Biotechnology Laboratory, University of British Columbia, performed the electrophoresis. If sequence ambiguities remained after alignment of the forward and reverse amplicons, DNA was re-extracted and resequenced, as above. Sequencher 4.10.1 (Gene Codes Corp., Ann Arbor, Michigan) was used to assemble the amplicons.

Taxon selection and alignments. - To retrieve sequences for Capnodiales, we used query sequences from the unknown

\footnotetext{
${ }^{2}$ Available at http://www.botany.duke.edu/fungi/mycolab

${ }^{3}$ Primer sequences available at http://www.lutzonilab.net/ primers/page244.shtml
} 
sooty mold and Conidiocarpus caucasicus. Additional sequences for Capnodiales were selected from Chomnunti et al. (2011), Crous et al. (2007, 2009) and Schoch et al. (2006, 2009a, b). Sequences for outgroups were selected from James et al. (2006). (http://wasabi.lutzonilab.net/ pub/alignments/download_alignments). Initially LSU and SSU rDNA regions were aligned separately with MAFFT (Katoh et al. 2005) through the EMBL-EBI server (http:// www.ebi.ac.uk/Tools/msa/mafft/) and edited manually with Se-Al Sequence Alignment Editor 2.0a11 (Rambaut 2002) and Mesquite 2.75 (Maddison and Maddison 2011). We excluded unalignable regions manually.

Phylogenetic analysis.-For analysis, the general time reversible (GTR) model along with a gamma distribution was selected using jModelTest 2.1 (Guindon and Gascuel 2003, Darriba et al. 2012). We used RAxML 7.4.2 (Stamatakis 2006) to run several preliminary phylogenetic analyses. After preliminary analysis (results not shown), we excluded sequences for the following capnodiaceous fungi from the datasets because the phylogenetic positions of these taxa conflicted between the LSU and SSU trees and we could not rule out that one or both of the sequences from each species came from a contaminant: Devriesia americana (LSU: EU040227; SSU: AY251100), Brunneosphaerella protearum (LSU: GU214394; SSU: JN938706), Pseudocercospora vitis (LSU: GU253844; SSU: DQ289864) and Passalora vaginae (LSU: GQ852624; SSU: GU214561). We also excluded a sequence that we had determined from a culture of Fumiglobus sp. (ATCC 22041) because our preliminary phylogenetic trees showed the fungus to be a member of Pleosporales rather than Capnodiaceae, indicating that the culture was probably that of a contaminant. The final alignment included 150 taxa with 1305 characters from the LSU and 1595 from the SSU. The concatenated dataset (LSU + SSU rDNA) was generated with Mesquite. GenBank accession numbers are provided (FIG. 1, SuPPLEMENTARY TABLE I). Alignment of the concatenated dataset is available at TreeBASE (http://purl.org/phylo/treebase/ phylows/study/TB2:S14550).

With RAxML, we performed separate maximum likelihood searches for alignments of: (i) partial LSU rDNA, (ii) partial SSU rDNA and (iii) a concatenated dataset encompassing both partial LSU and SSU rDNA genes. We performed 50 replicated likelihood searches followed by 500 bootstrap replicates for each dataset. The phylogenetic trees were rooted and modified with FigTree 1.4 (available at http://tree.bio.ed.ac.uk/software/figtree/) and Mesquite.

\section{RESULTS}

Phylogenetic analysis.-The unknown species of Fumiglobus, described below as "Fumiglobus pieridicola", is the first sequenced representative of its genus. "Fumiglobus pieridicola" is within Capnodiaceae, in a clade that also includes Capnodium coffeae, with $94 \%$ bootstrap support from the concatenated dataset (FIG. 1). Within Capnodiaceae, Scorias spongiosa is the earliest diverging taxon, although without bootstrap support (FIG. 1). Fumiglobus pieridicola is then sister to the rest of the Capnodiaceae (FIG. 1).

In the phylogeny of the Ascomycota, many of the same clades received support from the concatenated dataset (FIG. 1) and individual analysis of LSU and SSU dataset. We recovered strong support from the concatenated dataset for Capnodiales being monophyletic within Ascomycota and moderate support for it being the sister group to Dothideales (FIG. 1). The same topology appeared, although with less support, for the individual analysis of the 18S and 28S datasets (not illustrated).

As expected, the anamorphic type species Conidiocarpus caucasicus was part of a clade with three Conidiocarpus species, $C$. betle, $C$. siamensis and $C$. asiaticus, with $85 \%$ bootstrap support from the concatenated dataset (FIG. 1) and 89\% support from the SSU dataset. All Conidiocarpus species in the analysis except C. caucasicus have a sexual state, and because of this they had been placed in Phragmocapnias. The close relationship between the type species for the anamorph and the type species for the teleomorph supports Conidiocarpus as the anamorph of Phragmocapnias. However, Conidiocarpus (Jaczewski 1917) is an older name than Pragmocapnias (Theissen and Sydow 1918). By the rules of nomenclatural priority (Article No. 59, ICBN Melbourne Code, McNeill et al. 2012), the name of the holomorph genus is Conidiocarpus. This requires new combinations and reconsideration of current names, as explained below.

\section{TAXONOMY}

Fumiglobus pieridicola Tanay Bose, sp. nov.

(Figs. 2A, B, D-G, 3)

MycoBank MB803877

Mycelium epiphyllous, saprophytic, superficial, mucilaginous, spreading, dark brown-black. Hyphae light-dark brown, septate, constricted at septum, moniliform, smooth walled, branched irregularly, hyphal tips acute, cells 5.9(4.5-10.5) × 7.45(6-13.5) $\mu \mathrm{m} \quad(\mathrm{n}=100)$; immature hyphae hyaline or light brown, cells 2.4(1.5-3) × 3.9(3-4.5) $\mu \mathrm{m}(\mathrm{n}=100)$. Pycnidia superficial, apical and intercalary; apical pycnidia pyriform, $30(25-70) \times 25(23-67.5) \mu \mathrm{m}(\mathrm{n}=$ 75 ), with bulbous, multiseriate stalk (usually one or a few cells in diameter, variable length and width), $7.5(6-10) \times 7(6-8.5) \mu \mathrm{m}(\mathrm{n}=75)$, dark brown, glabrous, membranous, pseudoparenchymatous, wall of nearly isodiametric, 4-6-sided cells, ostiole fimbriate $10.5(6-12) \times 12(10.5-15) \mu \mathrm{m}(\mathrm{n}=75)$; intercalary pycnidia subglobose $30(25-65) \times 28(26-68) \mu \mathrm{m}$ $(\mathrm{n}=75)$ with lateral stalk (usually) $8(6.5-9) \times 9.3(8-$ 10) $\mu \mathrm{m}(\mathrm{n}=75)$. Conidia round to slightly oval, hyaline, often adhering in short chains, 1.75(1.5-4.5) $\mu \mathrm{m}(\mathrm{n}=100)$ diam, 1-4 guttulate. 
Host: Pieris japonica (Ericaceae), common name Japanese andromeda, and Arbutus menziesii (Ericaceae), common name Pacific madrone.

Insect associated with Japanese andromeda: Dr G.W. Watson identified the scale insect as Pulvinaria cf. acericola (Walsh and Riley 1868) (FIG. 2C). While the generic identity was clear, the species is uncertain.

Etymology: Growing on Pieris japonica.

Specimens examined: Unless otherwise specified, specimens were collected by $\mathrm{T}$. Bose on leaves of Pieris japonica. CANADA. BRITISH COLUMBIA: Vancouver, University of British Columbia (UBC), Point Grey Campus, near Chemistry Building, 15 Feb 2011, TBCAP211 (HOLOTYPE UBC F23788).

Additional specimens examined: CANADA. BRITISH COLUMBIA: Vancouver, UBC, Point Grey Campus, near Chemistry building, 15 Feb 2011, TBCAP212, UBC F23789; ibid., 13 Jun 2011 TBCAP213, UBC F23790; ibid., TBCAP214 UBC F23791; UBC, Point Grey Campus, near Cunningham building, 13 Jun 2011, TBCAP215, UBC F23792; ibid., TBCAP216, UBC F23793; ibid., TBCAP217, UBC F23794; UBC, Point Grey Campus, near the Museum of Anthropology, 13 Jun 2011, TBCAP218, UBC F23795; ibid., TBCAP219, UBC F23796; UBC, Point Grey Campus, Wesbrook Mall, near UBC Bus Loop, 13 Jun 2011, TBCAP220, UBC F23797; ibid., TBCAP221, F23798; Victoria, 80 High Street, on leaves of Arbutus menziesii, 29 August 1978, leg. J. A. Calder, DAVFP 21836. (Originally identified as Capnodium walteri, DAVFP 21836 is a mixed collection of C. walteri with Fumiglobus pieridicola). UNITED STATES OF AMERICA. OREGON: Corvallis, Oregon State University, Monroe and 16th Avenue, south sidewalk, 17 May 2013, leg. L. Le Renard and A. Bazzicalupo, TALORO02, UBC F23809; ibid., TALOROO3 UBC F23810; Corvallis, 2120 NW Harrison blvd, on P. japonica, 17 May 2013, leg. L. Le Renard and A. Bazzicalupo, TALOR001 UBC F23808.

Known distribution: West coast, N. America. Known from Vancouver British, Columbia, Victoria, British Columbia, Canada, and Corvallis, Oregon, USA. Possibly widely distributed worldwide where Pieris japonica is cultivated, but under-reported.

Additional Fumiglobus species examined: Fumiglobus citrinus (Bat. \& Cif.) D.R. Reynolds \& G.S. Gilbert 2006. [MycoBank MB522431]. Specimens examined, UC1999509, UC1999510. Fumiglobus didymopanacis (Bat. Nascim. \& Cif.) D.R. Reynolds \& G.S. Gilbert 2006. [MycoBank MB522430] (FIGS. 2H, I). Specimen examined, UC1994100. Fumiglobus ficina (Bat. Nascim. \& Cif.) D.R. Reynolds \& G.S. Gilbert 2006. [MycoBank MB520906]. Specimens examined, UC1999506, UC1999511, UC1999512, UC1999513. Fumiglobus juniperinus (Bacc.) D.R. Reynolds \& G.S. Gilbert 2006. [MycoBank MB522426]. Specimen examined, UC1999514.

Notes: Among Fumiglobus species, F. pieridicola has the smallest conidia (TABLE I). Fumiglobus pieridicola most closely resembles $F$. didymopanacis, but these species can be distinguished by their pycnidial and conidial morphology (TABLE I). Fumiglobus pieridicola has stalked pyriform pycnidia that are apical or intercalary (apical pycnidia mean $30 \times 25 \mu \mathrm{m}$ diam; intercalary pycnidia mean $30 \times 28 \mu \mathrm{m}$ diam) and isodiametric conidia with a mean $1.75 \mu \mathrm{m}$ diam. In $F$. didymopanacis both the pycnidia $(40-70 \times 43-60 \mu \mathrm{m})$ and conidia (av. $1.5 \times 2.2 \mu \mathrm{m}$ ) are slightly elongated (Batista and Ciferri 1963b) (FIGS. 2H, I). Batista and Ciferri (1963b) described the holotype of $F$. didymopanacis as having bacillar to globose conidia, but we were unable to find the rod-shaped conidia in the specimen. Cells making up the hyphae of $F$. pieridicola are almost isodiametric, with a mean length-to-width ratio of $1.3(1.16-1.44 ; \mathrm{n}=100)$, while those of $F$. didymopanacis are elongate, with a mean length-towidth ratio of $3.3(3.0-3.75 ; \mathrm{n}=100)$. Fumiglobus didymopanacis has been reported from Brazil and Australia growing on Artocarpus, Baccharis, Eucalyptus and Schefflera morototoni (三 Didymopanax morototoni) (Batista and Ciferri 1963b). Although the genus Fumiglobus had never been reported from a temperate region, its wide host range is consistent with the possibility of finding it on Pieris japonica.

Species excluded from Fumiglobus:

Asteridiella glabroides (F. Stevens) Hansf., Beih Sydowia 2:71. 1961. [MycoBank MB482083]

$\equiv$ Meliola glabroides F. Stevens 1916 .

$\equiv$ Asbolisia glabroides (F. Stevens) Speg.

$\equiv$ Fumiglobus glabroides (F. Stevens) D.R. Reynolds \& G.S. Gilbert 2006.

Notes: Asteridiella glabroides is not a capnodiaceous mold. Stevens (1916) described this epiphyllous fungus as Meliola glabroides. Later Spegazzini reclassified the fungus as Asbolisia glabroides. Along with other former Asbolisia, Reynolds and Gilbert (2006) transferred this species to Fumiglobus. However, Stevens' (1916) description and image clearly support its identity as a member of Meliolaceae. Hansford (1961) reclassified the fungus as Asteridiella after examining the type. We support this reclassification because, consistent with an identification of Asteridiella, the fungus has no perithecial or mycelial setae (Hosagoudar and Agarwal 2008).

Asbolisia inocarpi Bat., in Batista and Ciferri, Quad Lab crittogam Pavia 31:43. 1963b. [MycoBank MB326508] Specimen examined, UC1999515.

Note: This species was excluded by Reynolds and Gilbert (2006), who reported that the holotype (UC1999515) does not have the characters of Fumiglobus and should be transferred to Polychaeton.

Cicinnobella ampullula (Speg.) Petr. \& Syd., Ann Mycol 33:190. 1935. [MycoBank MB256728]

$\equiv$ Asbolisia ampullula (Speg.) Speg., Physis Revista de la Sociedad Argentina de Ciencias Naturales 4:293. 1918. 


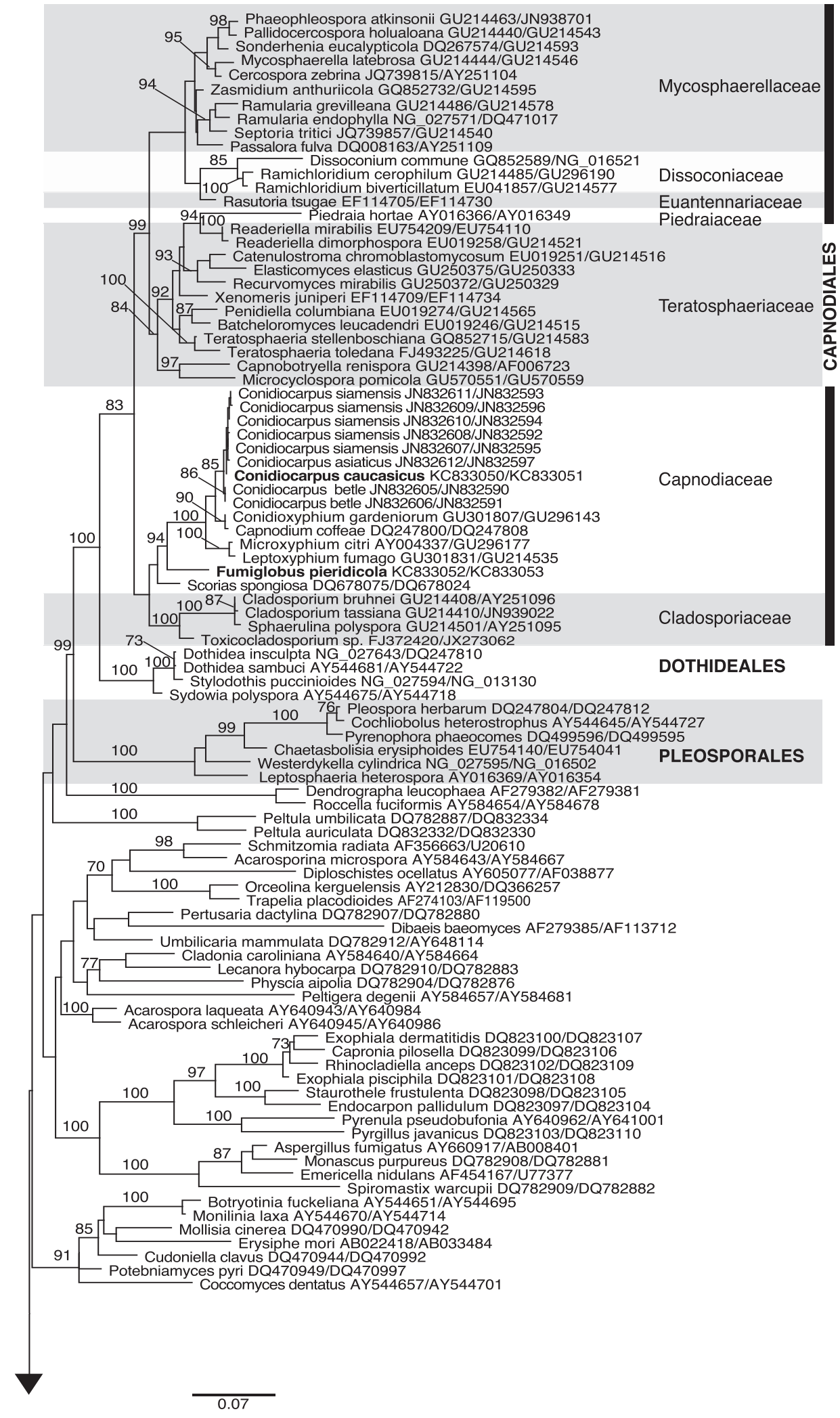

FIG. 1. Fumiglobus pieridicola and Conidiocarpus caucasicus, in boldface, represent new sequences from this study and are well supported as members of the Capnodiaceae. This maximum likelihood tree was generated with RAxML for concatenated ribosomal large and small subunit sequences. Numbers are bootstrap values from 500 replicates. GenBank accession numbers, LSU/SSU, follow names. Bar indicates number of substitutions per site. 


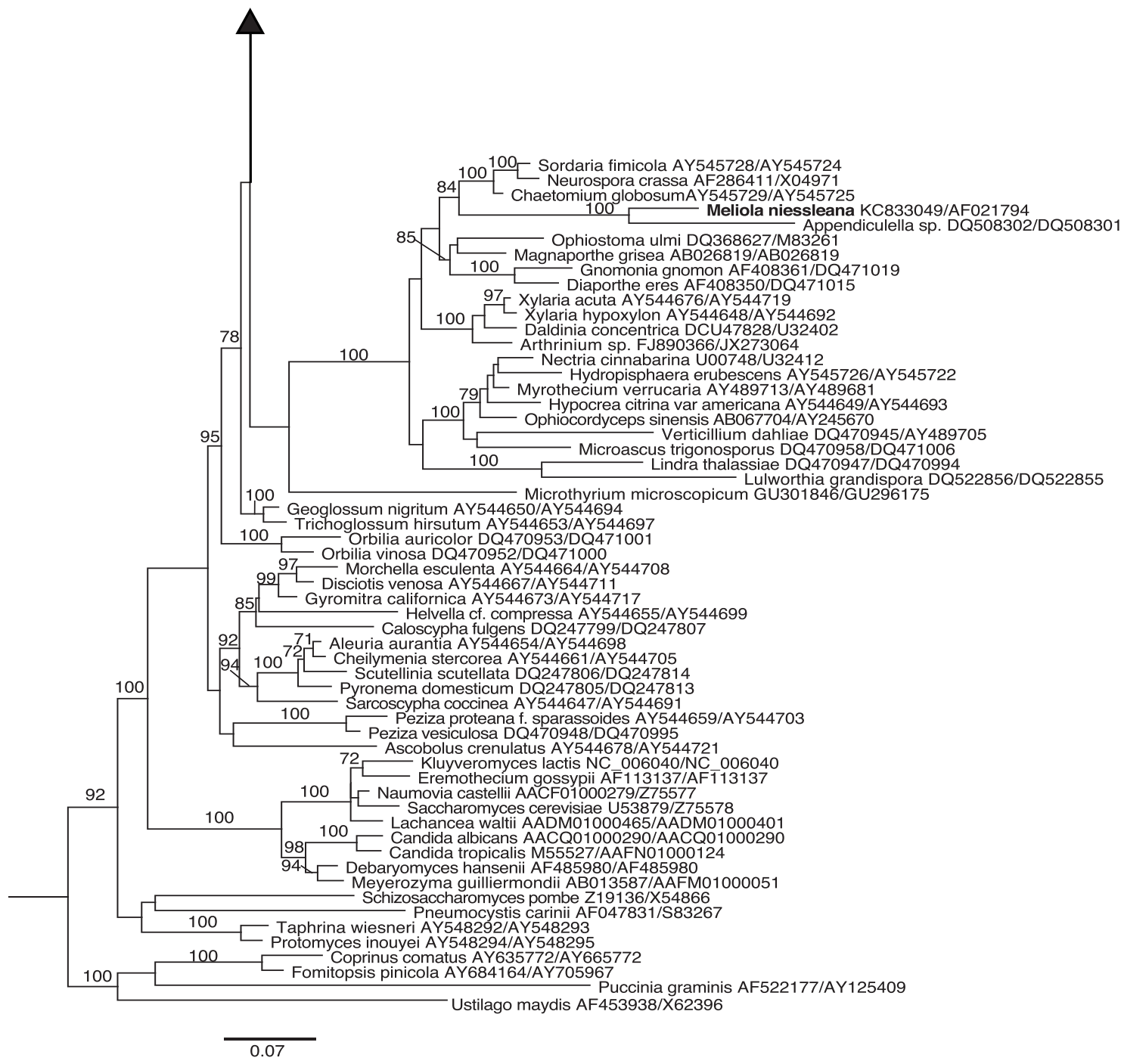

FIG. 1. Continued.

$\equiv$ Fumiglobus ampullula (Speg.) D.R. Reynolds \& G.S. Gilbert, Cryptogamie: Mycol 27:254. 2006.

Notes: Asbolisia ampullula is the type of Asbolisia. Petrak and Sydow (1935) treated this species as Cicinnobella ampullula (Speg.) Petr. \& Syd., a decision that was supported by Hughes (1976). Batista and Ciferri (1963b) attempted to conserve the genus Asbolisia by proposing Asbolisia citrina Bat. \& Cif., an indigenous Brazilian species, as its lectotype. However, as Hughes (1976) pointed out that this was an invalid approach to generic conservation. Following Petrak and Sydow (1935) and Sutton (1977), Kirk et al. (2008) designated Asbolisia as nomen dubium. Reynolds and Gilbert (2006) erected Fumiglobus for former Asbolisia species, but they inadvertently transferred A. ampullula to Fumiglobus as well. Here, we acknowledge this error and recognize $F$. ampullula as a synonym of Cicinnobella ampullula.
Current names and synonymy for Conidiocarpus species: Conidiocarpus caucasicus Woron., p 743 in A.A. Jaczewski (= A.A. Yachevsky, an alternative transliteration), Opredelitel' gribov. T.2. Nesovershennie gribi. Petrograd. 1917. [MycoBank MB803878] Specimens examined: GUMH 937, UBC F23755.

Notes: This is the type species of Conidiocarpus as discussed by Hughes (1976). Hughes cites the reference title in English not Russian as "Key to Fungi. Vol. 2. Fungi imperfecti".

Conidiocarpus asiaticus (Chomnunti \& K.D. Hyde) Tanay Bose, comb. nov. [MycoBank MB807017]

$=$ Phragmocapnias asiaticus Chomnunti \& K.D. Hyde. 2011.

Conidiocarpus betle (Syd. P Syd. \& E.J. Butler) Tanay Bose, comb. nov. [MycoBank MB807018] 

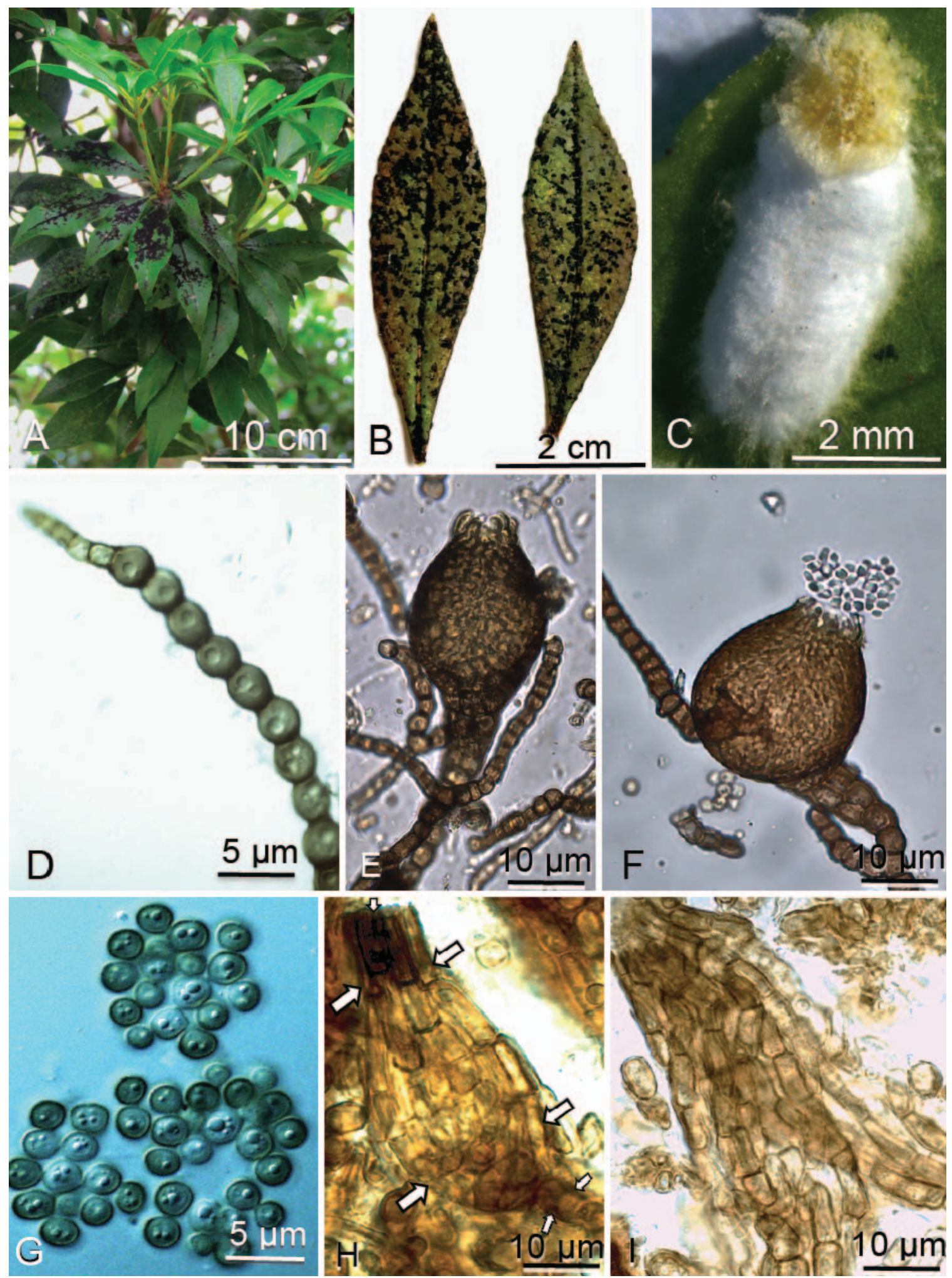

FIG. 2. Fumiglobus pieridicola (A, B, D-G). A, B. Mycelium on adaxial surfaces of leaves of host Pieris japonica (Japanese andromeda). C. Pulvinaria cf. acericola, a scale insect on $P$. japonica, produces the honeydew that nourishes the mold $F$. pieridicola. D. Portion of a moniliform hypha. E. Mature apical pycnidium. F. Mature intercalary pycnidium. G. Conidia. H, I. Fumiglobus didymopanacis (Holotype UC 1994100). H. Pycnidium, with its outline indicated by arrows. I. Mycelium composed of elongated cells. 


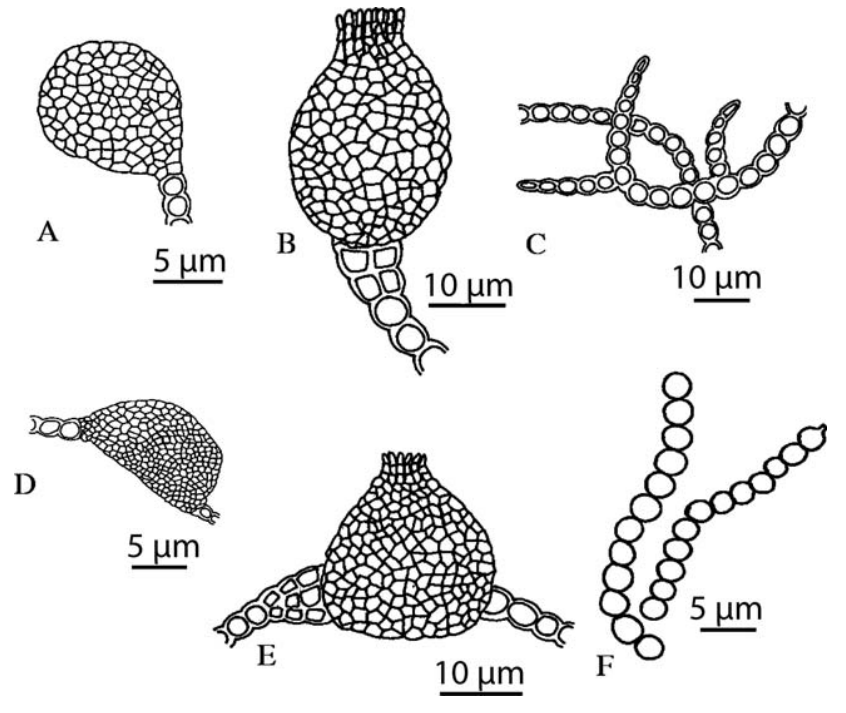

FIG. 3. Microscopic structures of Fumiglobus pieridicola on Pieris japonica (Japanese andromeda). A. Immature apical pycnidium. B. Mature apical pycnidium. C. Hyphae. D. Immature intercalary pycnidium. E. Mature intercalary pycnidium. F. Chains of conidia from pycnidium.

$\equiv$ Capnodium betle Syd. P. Syd. \& E.J. Butler. 1911.

$\equiv$ Phragmocapnias betle (Syd. P Syd. \& E.J. Butler) Theiss. \& Syd. 1918.

Conidiocarpus callitris (McAlpine) Tanay Bose, comb. nov. [MycoBank MB807019]

$\equiv$ Capnodium callitris McAlpine. 1896.

$\equiv$ Limacinia callitris (McAlpine) Sacc. \& P Syd. 1899.

= Phragmocapnias callitris (McAlpine) Cif. \& Bat. 1963.

Conidiocarpus fuliginodes (Rehm) Tanay Bose, comb. nov. [MycoBank MB807020]

$\equiv$ Capnodium fuliginodes Rehm. 1874 .

$\equiv$ Meliola fuliginodes (Rehm) Sacc. 1882.

$\equiv$ Limacinia fuliginoides (Rehm) Sacc. 1899.

$\equiv$ Capnophaeum fuliginoides (Rehm) W. Yamam. 1954.

=Phragmocapnias fuliginoides (Rehm) Cif. \& Bat. 1963.

Conidiocarpus heliconiae (Cif. \& Bat.) Tanay Bose, comb. nov. [MycoBank MB807021]

= Phragmocapnias heliconiae Cif. \& Bat. 1963.
Conidiocarpus imperspicuus (Sacc.) Tanay Bose, comb. nov. [MycoBank MB807022]

$\equiv$ Limacinia imperspicua Sacc. 1917.

= Phragmocapnias imperspicua (Sacc.) Cif. \& Bat. 1963.

Conidiocarpus longicollus Matsush. 2003. [MycoBank MB374479]

三Phragmocapnias longicollus (Matsush.) Chomnunti \& K.D. Hyde 2011.

Conidiocarpus penzigii Woron., Ann. Mycol. 24:250. 1927. [MycoBank MB273921]

= Phragmocapnias penzigii (Woron.) Chomnunti \& K.D. Hyde 2011.

Conidiocarpus siamensis (Chomnunti \& K.D. Hyde) Tanay Bose, comb. nov. [MycoBank MB807059]

$\equiv$ Phragmocapnias siamensis Chomnunti \& K.D. Hyde 2011.

\section{DISCUSSION}

This is the first report of a Fumiglobus species from a temperate region and the first report of a species in Capnodiaceae on Japanese andromeda (Partyka 1980, Farr et al. 1989, Jones and Benson 2001, Sinclair and Lyon 2005). Although sap-sucking insects have been reported on the host plant in both North America and the United Kingdom, the accompanying fungi previously were not identified or vouchered (Schread 1970, Partyka 1980).

Because $F$. pieridicola is locally common and striking in appearance, we initially assumed it would have been collected frequently and that, knowing its genus, we would be able to determine its distribution pattern through herbarium records. However, neither UBC nor DAVFP, important herbaria in our region with digitized collections, had any specimens identified as Fumiglobus (or Asbolisia); neither did DAOM, the National Mycological Herbarium in Ottawa, Ontario, Canada. Having the collections of Stanley J. Hughes, a leading authority on Capnodiaceae, DOAM would have been one of the most likely repositories of Fumiglobus specimens.

TABle I. Comparison of pycnidia and conidia of the new species Fumiglobus pieridicola with previously described Fumiglobus species

\begin{tabular}{lclll}
\hline \hline \multicolumn{1}{c}{ Taxa } & Dimension of pycnidium & Size of conidia & Shape of conidia & Septation in conidia \\
\hline Fumiglobus pieridicola & $30 \times 25 \mu \mathrm{m}$ & $1.75 \mu \mathrm{m}$ & spherical & absent \\
F. citrinus & $50-55 \times 36-40 \mu \mathrm{m}$ & $2-4.5 \times 1 \mu \mathrm{m}$ & filiform & absent \\
F. didymopanacis & $40-70 \times 43-60 \mu \mathrm{m}$ & $1.5 \times 2.2 \mu \mathrm{m}$ & ovoid & absent \\
F. ficina & $85-100 \mu \mathrm{m}($ diam $)$ & $3.5-4 \times 1-1.5 \mu \mathrm{m}$ & ellipsoidal & absent \\
F. foedus & $\sim 50 \mu \mathrm{m}($ diam $)$ & $3-4.5 \mu \mathrm{m}$ & spherical & absent \\
F. indicus & $160 \times 60-150 \mu \mathrm{m}$ & $6.5 \times 5.5 \mu \mathrm{m}$ & ellipsoidal & absent \\
F. juniperinus & $54-90 \mu \mathrm{m}($ diam $)$ & $6.4 \times 11.8 \mu \mathrm{m}$ & elongate & $2-3$ septate \\
\hline
\end{tabular}


Because no specimens labeled Fumiglobus or Asbolisia were available in regional herbaria, we examined the only available specimens of Capnodiaceae on other ericaceous plants from our regional herbaria, which were two specimens of Capnodium walteri on madrone from DAVFP. Capnodium walteri has elongate, multiseptate conidia and is clearly different from $F$. pieridicola. One of these specimens, DAVFP 21836, was a mixed collection containing $F$. pieridicola along with the mitospore state of $C$. walteri. In his original description of C. walteri, Saccardo (1893) said that it had spermogonia. This raised the question of whether $F$. pieridicola could represent the spermogonial stage of $C$. walteri that Saccardo illustrated or on the other hand whether $F$. pieridicola and $C$. walteri are two separate taxa growing in proximity. Saccardo's illustration of spermogonia (1893: FIG. 1a, TABLE VI) shows an obclavate sporulating body, elevated on a stout multicellular stalk several cells in diameter, lacking fimbriae around the ostiole. In contrast, $F$. pieridicola has pyriform pycnidia, a slender stalk and fimbriae around the ostiole. The "conidia" produced by the putative spermogonia of $C$. walteri were oblong and at $5 \times$ $2 \mu \mathrm{m}$ (Saccardo 1893; FIg. 1d, TABLE VI) were more than twice as long as conidia of $F$. pieridicola. Saccardo's description of C. walteri is confusing in several respects, and in addition to showing spermogonia he described and illustrated characters now recognized to be absent in $C$. walteri including pycnidia resembling Microxyphium (Fraser 1935) and an ascoma with an elongated neck (Fraser 1935, Batista and Ciferri 1963a, Hughes 1976, Sivanesan 1984). The spermogonia seen by Saccardo were not reported again afterward by Fraser (1935) in her descriptions of C. walteri or by Hughes (1976), although neither Hughes nor Fraser examined the holotype. We think Saccardo was analyzing a mixed colony of sooty molds and that the "spermogonia" were mitospore fruiting bodies of a different sooty mold. It is most likely that $F$. pieridicola and $C$. walteri are two separate species that were growing closely together, as is common for sooty molds.

The phylogeny of Capnodiales was mostly congruent with trees published by Crous et al. (2009), Schoch et al. (2009a) and Chomnunti et al. (2011), where taxon sampling overlapped. Sequences from genera traditionally placed in Capnodiaceae formed a monophyletic group that included $F$. pieridicola. Moniliform hyphae as in $F$. pieridicola are not usual in Capnodiaceae, but on the other hand pycnidia with fimbrae around the ostiole and the mucilaginous sheath around hyphae are typical of the family and rule out alternative placements (Hughes 1972, 1976). Of the genera in Capnodiaceae, Scorias, Conidiocar- pus, Conidioxyphium, Microxyphium and Leptoxyphium share a pycnidial stage with a horn-shaped, elongated neck and the pycnidium is usually elevated on a long black stalk (Batista and Ciferri 1963b, Hughes 1976). Fumiglobus (Reynolds and Gilbert 2006) represents the simplest type of fruiting structures among all pycnidial anamorphs from Capnodiaceae with simple globose to pyriform pycnidia that lack the elongated stalk and neck. Fumiglobus has no known teleomorph, raising the possibility that our species is an anamorph of a previously described teleomorph. However, our phylogeny shows that $F$. pieridicola cannot be monophyletic with any of the sequenced teleomorph genera.

Although this study was successful in establishing the phylogenetic position of Fumiglobus, its family, Capnodiaceae, remains poorly sampled. Contamination remains the major barrier in the molecular systematics of Capnodiales. This was evident when our sequencing revealed that a culture of Fumiglobus sp. (ATCC 22041) was a member of the Pleosporales not Capnodiales. The sequences in GenBank for Chaetasbolisia erysiphoides strain CBS 148.94 (LSU: EU754140; SSU: EU754041) similarly suggested that the fungal isolate could be a contaminant. From its morphology, Chaetasbolisia erysiphoides belongs in Capnodiaceae and like Fumiglobus it has subglobose pycnidia with hyaline conidia (Batista and Ciferri 1963b). In our phylogeny, C. erysiphoides nested within Pleosporales with high bootstrap support and not in the Capnodiales. Isolating DNA or a pure culture from a foliicolous fungus is clearly difficult.

Finding $F$. pieridicola so commonly on a non-native shrub raised the possibility that the fungus is a recent introduction. Pieris japonica is native to eastern Asia, and, although we found no Asian reports of the fungus, it may coexist there with its plant host. However, we also found $F$. pieridicola on leaves of a native madrone tree. Fumiglobus pieridicola must have dispersed at least $600 \mathrm{~km}$ because we documented its presence in Corvallis Oregon, USA, and in Victoria and Vancouver. British Columbia, Canada. We speculate that the fungus may accompany early instar scale insects as they crawl to a feeding site or winged males during flight to find a mate. The lack of information about this locally common fungus brings to mind a quote used by Linnaeus (1751 p 158), "Nomina si nescis, perit et cognitio rerum". Now that the fungus has a name, we hope that it will become more widely collected and accessioned into herbaria, leading to a more complete understanding of its biology and geographical distribution.

\section{ACKNOWLEDGMENTS}

Dr G. Reza Balali, Department of Biology, Isfahan University, Iran, provided the Conidiocarpus caucasicus 
specimen. Dr Gillian W. Watson, California Department of Food \& Agriculture, Sacramento, identified the scale insect on Pieris japonica. Dr Arthur de Cock, CBS-KNAW Fungal Biodiversity Centre, Utrecht, the Netherlands, and Dr John L. Strother, University Herbarium, University of California, Berkeley, provided helpful advice on orthography of names for Fumiglobus and Conidiocarpus species. Thanks to UC and DAVFP for providing us with the herbarium specimens. Thanks Dr S.A. Khoderparast for translation from Persian to English and to Lola Millerman (née Bakhareva) for translations from Russian to English. Prof Sean W. Graham and Prof Quentin C.B. Cronk, Department of Botany, University of British Columbia, Vancouver, provided useful feedback during this study. The UBC Beaty Museum kindly let us use their stereomicroscope for photography of the scale insects. A Discovery Grant from the Natural Sciences and Engineering Research Council of Canada to M.L. Berbee supported this research.

\section{LITERATURE CITED}

Andrew JH. 1992. Biological control in the phyllosphere. Annu Rev Phytopathol 30:603-635, doi:10.1146/annurev. py.30.090192.003131

Batista AC, Ciferri R. 1963a. Capnodiales. Pavia, Italy: R. Cortina. 298 p.

- 1963b. The sooty molds of the family Asbolisiaceae. Quaderno/Istituto botanico della Università. Laboratorio crittogamico Pavia 31:1-216.

Blakeman JP, Fokkema NJ. 1982. Potential for biological control of plant diseases on the phylloplane. Annu Rev Phytopathol 20:167-192, doi:10.1146/annurev.py. 20.090182 .001123

Buczacki ST, Harris KM, Hargreaves B. 1981. Collins guide to the pests, diseases and disorders of garden plants. Glasgow, UK: Collins. 512 p.

Chomnunti P, Schoch CL, Aguirre-Hudson B, Ko-Ko TW, Hongsanan S, Jones EBG, Kodsueb R, Phookamsak R, Chukeatirote E, Bahkali AH, Hyde KD. 2011. Capnodiaceae. Fungal Divers 51:103-134, doi:10.1007/ s13225-011-0145-6

Crous PW, Braun U, Groenewald JZ. 2007. Mycosphaerella is polyphyletic. Stud Mycol 58:1-32, doi:10.3114/ sim.2007.58.01

- Schoch CL, Hyde KD, Wood AR, Gueidan C, de Hoog GS, Groenewald JZ. 2009. Phylogenetic lineages in the Capnodiales. Stud Mycol 64:17-47, doi:10.3114/ sim.2009.64.02

Darriba D, Taboada GL, Doallo R, Posada D. 2012. jModelTest 2: more models, new heuristics and parallel computing. Nat Methods 9:772, doi:10.1038/ nmeth.2109

Dhami MK, Weir BS, Taylor MW, Beggs JR. 2013. Diverse honeydew-comsuming fungal communites associated with scale insects. PLoS ONE 8, doi:10.1371/journal. pone.0070316

Farr DF, Bills GF, Chamuris GP, Rossman AY. 1989. Fungi on plants and plant products in the United States. St Paul, Minnesota: APS Press. 1252 p.
Fraser L. 1935. An investigation of the sooty molds of New South Wales IV. The species of the Eucapnodieae. Proc Linn Soc NSW 40:159-178.

Gargas A, Taylor JW. 1992. Polymerase chain reaction (PCR) primers for amplifying and sequencing nuclear $18 \mathrm{~S}$ rDNA from lichenized fungi. Mycologia 48:589592, doi: $10.2307 / 3760327$

Guindon S, Gascuel O. 2003. A simple, fast and accurate algorithm to estimate large phylogenies by maximum likelihood. Syst Biol 52:696-704, doi:10.1080/ 10635150390235520

Hansford CG. 1961. The Meliolineae, a monograph. Beih Sydowia 2:1-806.

Hollingsworth CS. 2013. Pacific Northwest insect management handbook. Corvallis: Oregon State Univ, http:/ / pnwhandbooks.org/insect/pacific-northwest-insectmanagement-handbook/citing-handbook\#sthash. VEI018eS.dpuf (Accessed 30 Nov 2013).

Hosagoudar VB, Agarwal DK. 2008. Taxonomic studies of Meliolales: identification manual. Dehradun India: International Book Distributors. 263 p.

Hughes SJ. 1972. New Zealand Fungi 17. Pleomorphism in Euantaennariaceae and Metacapnodiaceae, two families of sooty molds. N Z J Bot 10:225-242, doi:10.1080/ 0028825X.1972.10429151

——— 1976. Sooty molds. Mycologia 68:693-820, doi:10.2307/3758799

Jaczewski AA. 1917. Opredelitel' gribov. T.2. Nesovershennie gribi. Petrograd, Russia.

James A, Dungan R, Plank M, Ito R. 2007. A dynamical model of honeydew droplet production by sooty-beech scale insects (Ultracoelostoma spp.) in New Zealand Nothofagus forest. Ecol Model 209:323-332, doi:10.1016/j.ecolmodel.2007.06.024

James TY, Kauff F, Schoch CL, Matheny PB, Hofstetter V, Cox CJ, Celio G, Gueidan C, Fraker E, Miadlikowska J, Lumbsch HT, Rauhut A, Reeb V, Arnold AE, Amtoft A, Stajich JE, Hosaka K, Sung GH, Johnson D, O'Rourke B, Crockett M, Binder M, Curtis JM, Slot JC, Wang Z, Wilson AW, Schuszler A, Longcore JE, O'Donnell K, MozleyStandridge S, Porter D, Letcher PM, Powell MJ, Taylor JW, White MM, Griffith GW, Davies DR, Humber RA, Morton JB, Sugiyama J, Rossman AY, Rogers JD, Pfister DH, Hewitt D, Hansen K, Hambleton S, Shoemaker RA, Kohlmeyer J, Volkmann-Kohlmeyer B, Spotts RA, Serdani M, Crous PW, Hughes KW, Matsuura K, Langer E, Langer G, Untereiner WA, Lucking R, Budel B, Geiser DM, Aptroot A, Diederich P, Schmitt I, Schultz M, Yahr R, Hibbett DS, Lutzoni F, McLaughlin DJ, Spatafora JW, Vilgalys R. 2006. Reconstructing the early evolution of Fungi using a six-gene phylogeny. Nature 443:818-822, doi:10.1038/nature05110

Jones RK, Benson DM. 2001. Diseases of woody ornamentals and trees in nurseries. St Paul, Minnesota: APS Press. 482 p.

Katoh K, Kuma K, Toh H, Miyata T. 2005. MAFFT 5: improvement in accuracy of multiple sequence alignment. Nucleic Acids Res 33:511-518, doi:10.1093/nar/gki198

Kelly D. 1990. Honeydew density in mixed Nothofagus forest, Westland, New Zealand. N Z J Bot 28:53-58, doi:10.1080/0028825X.1990.10412343 
Kirk PM, Cannon PF, Minter DW, Stalpers JA. 2008. Dictionary of the Fungi. Wallingford, UK: CABI. 747 p.

Khodaparast SA. 2006. A survey on citrus sooty mold fungi in Gilan Province, Iran. Rostaniha 7:59-65 (in Persian).

Linnaeus C. 1751. Philosophia botanica. Stockholm, Sweden: Godofr. Kiesewetter. 402 p.

Lumbsch HT, Huhndorf SM. 2010. Myconet. Vol. 14. Outline of Ascomycota-2009. Notes on ascomycete systematics. Nos. 4751-5113. Fieldiana Life Earth Sci 1: 1-64, doi:10.3158/1557.1

Maddison WP, Maddison DR. 2011. Mesquite 2.75: a modular system for evolutionary analysis. http:// mesquiteproject.org

McAlpine D. 1896. Two additions to the fungi of New South Wales. Proc Linn Soc N S W 21:722-724.

McNeill J, Barrie FR, Buck WR, Demoulin V, Greuter W, Hawksworth DL, Herendeen PS, Knapp S, Marhold K, Prado J, Prud'homme van Reine WF, Smith GF, Wiersema JH, Turland NJ. 2012. Names of anamorphic fungi or fungi with a pleomorphic life cycle. Chapter VIII. International code of nomenclature for algae, fungi and plants (Melbourne Code). Koenigstein, Germany: Koeltz Scientific Books.

Partyka RE. 1980. Woody ornamentals: plants and problems. Columbus, Ohio: ChemLawn Corp. 427 p.

Petrak F, Sydow H. 1935. Kritisch-Systematische Originaluntersuchungen über Pyrenomyceten, Sphaeropsideen und Melanconieen VI. Ann Mycol 33:190-191.

Rambaut A. 2002. Se-Al sequence alignment editor, 2.0a11. Oxford, UK: Univ. Oxford Press, http://tree.bio.ed.ac. uk/software/seal/

Reynolds DR. 1976. Observations on growth forms of sooty mold Fungi. Nova Hedwigia 26:179-193.

- 1998. Capnodiaceous sooty mold phylogeny. Can J Bot 76:2125-2130.

—, Gilbert GS. 2006. Epifoliar Fungi from Panama. Cryptogam Mycol 27:249-270.

Saccardo PA. 1893. Mycetes aliquot Australienses. Series quarta. Hedwigia 32:56-59.

Schoch CL, Crous PW, Groenewald JZ, Boehm EWA, Burgess TI, de Gruyter J, de Hoog GS, Dixon LJ, Grube M, Gueidan C, Harada Y, Hatakeyama S, Hirayama K, Hosoya T, Huhndorf SM, Hyde KD, Jones EBG, Kohlmeyer J, Kruys A, Li YM, Lucking R, Lumbsch HT, Marvanova L, Mbatchou JS, McVay AH, Miller AN, Mugambi GK, Muggia L, Nelsen MP, Nelson P, Owensby CA, Phillips AJL, Phongpaichit S, Pointing SB, PujadeRenaud V, Raja HA, Plata ER, Robbertse B, Ruibal C, Sakayaroj J, Sano T, Selbmann L, Shearer CA, Shirouzu T, Slippers B, Suetrong S, Tanaka K, VolkmannKohlmeyer B, Wingfield MJ, Wood AR, Woudenberg JHC, Yonezawa H, Zhang Y, Spatafora JW. 2009a. A classwide phylogenetic assessment of Dothideomycetes. Stud Mycol 64:1-15, doi:10.3114/sim.2009.64.01

, Shoemaker RA, Seifert KA, Hambleton S, Spatafora JW, Crous PW. 2006. A multigene phylogeny of the Dothideomycetes using four nuclear loci. Mycologia 98: 1041-1052, doi:10.3852/mycologia.98.6.1041
— kowska J, Hofstetter V, Robbertse B, Matheny PB, Kauff F, Wang Z, Gueidan C, Andrie RM, Trippe K, Ciufetti LM, Wynns A, Fraker E, Hodkinson BP, Bonito G, Groenewald JZ, Arzanlou M, de Hoog GS, Crous PW, Hewitt D, Pfister DH, Peterson K, Gryzenhout M, Wingfield MJ, Aptroot A, Suh S-O, Blackwell M, Hillis DM, Griffith GW, Castlebury LA, Rossman AY, Lumbsch HT, Luecking R, Buedel B, Rauhut A, Diederich P, Ertz D, Geiser DM, Hosaka K, Inderbitzin P, Kohlmeyer J, Volkmann-Kohlmeyer B, Mostert L, O'Donnell K, Sipman H, Rogers JD, Shoemaker RA, Sugiyama J, Summerbell RC, Untereiner W, Johnston PR, Stenroos S, Zuccaro A, Dyer PS, Crittenden PD, Cole MS, Hansen K, Trappe JM, Yahr R, Lutzoni F, Spatafora JW. 2009b. The Ascomycota tree of life: a phylumwide phylogeny clarifies the origin and evolution of fundamental reproductive and ecological traits. Syst Biol 58:224239, doi:10.1093/sysbio/syp020

Schread JC. 1970. Control of scale insect and mealy bugs on ornamentals. New Haven, Connecticut: Bulletin of the Connecticut Agricultural Experimental Station. Vol. 710.

Sharma ND, Agarwal GP. 1977. Fungi causing plant diseases at Jabalpur, Madhya Pradesh, India, 15. Some Sphaeropsidales. Sydowia 30:290-296.

Sinclair WA, Lyon HL. 2005. Diseases of trees and shrubs. Ithaca, New York: Cornell Univ. Press. 660 p.

Sivanesan A. 1984. The bitunicate Ascomycetes and their anamorphs. Vaduz, Liechtenstein: J. Cramer. 526 p.

Spegazzini C. 1918. Notas micológicas. Physis Rev Soc Argent Cienc Nat 4:281-295.

Stamatakis A. 2006. RAxML-VI-HPC: maximum likelihoodbased phylogenetic analyses with thousands of taxa and mixed models. Bioinformatics 22:2688-2690, doi:10.1093/bioinformatics/btl446

Stevens FL. 1916. The genus Meliola in Porto Rico. Ill Biol Monogr 2:475-554.

- 1931. A misnomer in the use of the term sooty mold. Philipp Agric 19:549.

Sutton BC. 1977. Coelomycetes VI. Nomenclature of generic names proposed for Coelomycetes. Mycol Pap 141:1-253.

Theissen F. 1915. Mykologische Abhandlungen. Verhandlungen der Zoologisch-Botanischen Gesellschaft, Wien 66:296-400.

— 389-491.

Vilgalys R, Hester M. 1990. Rapid genetic identification and mapping of enzymatically amplified ribosomal DNA from several Cryptococcus species. J Bacteriol 172:4238-4246.

Walsh BD, Riley CV. 1868. A new bark louse on the osage orange. Am Ent 1:14, doi:10.4039/Ent114-2

White TJ, Bruns T, Lee S, Taylor J. 1990. Amplification and direct sequencing of fungal ribosomal RNA genes for phylogenetics. In: Innis MA, Gelfand DH, Sninsky JJ, White TJ, eds. PCR protocols: a guide to methods and applications. New York: Academic Press. p. 315-322. 